\title{
Narratives and Practices of Voluntary Simplicity in the Czech Post-Socialist Context*
}

\author{
LUKÁŠ KALA, LUCIE GALČANOVÁ and VOJTĚCH PELIKÁN** \\ Masaryk University, Brno
}

\begin{abstract}
Voluntary simplicity is usually seen as an alternative social movement that is responding to the current social and environmental crisis within affluent societies. Many scholars draw on Inglehart's concept of post-materialism and consider voluntary simplicity to be a way of limiting one's consumption in order to free oneself and seek satisfaction in the non-material aspects of life. These scholars assume that the values associated with simplicity emerge out of over-saturation with consumption. This article discusses the results of research conducted among Czech households who voluntarily reduce consumption and who do so in a post-socialist context, without having first lived in affluence. Theoretically and methodologically, the article builds on the work of Hana Librová [1994, 2003; Librová et al. 2016] and is rooted in three main concepts: the concepts of post-materialism [Inglehart 1977], 'new luxury' [Enzensberger 1996], and the normative ethical theories of motivation [Pelikán and Librová 2015]. The findings of the study call into question Inglehart's structural assumption that non-consumption lifestyles like voluntary simplicity only develop in affluent societies and suggest that the Czech socialist past created conditions suitable for the emergence of a non-ideological and primarily self-oriented version of voluntary simplicity. The roots of simple lifestyles may also lie in people's dissatisfaction with the promise of modernity, a promise suggesting that it is possible to attain and lead the good life through material abundance. Prior experience with an affluent lifestyle did not play a role in the decision of participants in this study to live a nonconsumption lifestyle. This study in a post-socialist country therefore has the potential to provide a deeper understanding of the motivations for choosing voluntary simplicity.
\end{abstract}

Keywords: voluntary simplicity, non-consumption lifestyles, theory of postmaterialism, motivations for simplicity, post-socialism

Sociologický časopis/Czech Sociological Review, 2017, Vol. 53, No. 6: 833-855

https://doi.org/10.13060/00380288.2017.53.6.377

\footnotetext{
* Acknowledgements: We would like to thank Kateřina Prajznerová for the translation, Professor Hana Librová for her inspiration, and the participants in our research who were willing to share their stories. We thank also the reviewers for their careful reading of our manuscript and their insightful comments and suggestions. Financial support for this study was provided by the Czech Science Foundation for the project 'The Environmentally Friendly Lifestyle in the March of Time' (GA15-05552S).

** Direct all correspondence to: Lukáš Kala, Masaryk University, Joštova 218/10, 60200 Brno, Czech Republic, e-mail: lukas.kala@gmail.com.
}

(C) Sociologický ústav AV ČR, v.v.i., Praha 2017 


\section{Introduction}

Over the past two decades, there has been a growing interest among social scientists in researching consumption or non-consumption lifestyles ${ }^{1}$ [e.g. Grigsby 2004; Cherrier 2009; Etzioni 2013]. The emergence of non-consumption forms of lifestyle is usually linked with the Inglehartian cultural shift from materialist to post-materialist values ${ }^{2}$ [e.g. Myers 2003: 47]. However, the link between lifestyle choice and materialism has not been fully investigated ${ }^{3}$ [see Craig-Lees and Hill 2002: 189]. Moreover, lifestyles based on non-material values and simplicity have been part of Western culture since at least antiquity ${ }^{4}$ [see Alexander and McLeod 2014]. As Hana Librová observes, 'A look at history shows that the desire for simplicity and the equation of simplicity with the good life have been a constant in many traditions of thought. It is a remarkable reaction to the prevailing tendency of the human, and probably also the natural, world to grow in complexity and diversity' [Librová 2008]. It is not therefore for certain that, in the context of current non-consumption practices, we can talk about a value revolution or a cultural shift.

One of the frequently mentioned forms of non-consumption practices is voluntary simplicity [e.g. Zavestoski 2002; Cherrier 2009; Roux 2007]. It is often viewed as a general term for variously motivated non-materialistic lifestyles that reject high consumption and affirm 'the simple life' [Alexander 2011; Iwata 2006; Etzioni 1998]. Some scholars consider voluntary simplifiers to be trailblazers who

\footnotetext{
${ }^{1}$ Despite the considerable academic interest in non-consumption attitudes and anticonsumption practices, there is little consensus about what these terms actually mean. However, some attempts to create an integrative framework have been made [see, e.g., Roux 2007]. The most reputable authors in the field [Lee et al. 2011: 1681] use the term anticonsumption to refer to the phenomenon of when consumers are against the acquisition, use, and dispossession of certain goods. For Cherrier [2009], anti-consumption means both activity and attitude. The term anti-consumption implies an act of opposition, or even 'resistance', and it is often understood as 'an act against pervasive structures of domination of consumer culture' [Penaloza and Price 1993: 123; Valor et al. 2017].

2 Ronald Inglehart's hypothesis [1977, 1990] supported by international longitudinal surveys represents the most significant theoretical contribution to the discussion on the change in values from materialist to post-materialist values. The explanations for this change rest on 'the scarcity hypothesis' and 'the socialisation hypothesis'. Inglehart assumes that an individual's values reflect his or her socioeconomic environment and early socialisation. He asserts that post-material values develop either because of one's adolescent socialisation in relative abundance or because of society becoming affluent.

3 However, Elgin's [1981] groundbreaking work about the 'quiet revolution' of voluntary simplicity clearly builds on Inglehart's hypotheses and it has found support in follow up studies that point out the prevailing (upper-)middle-class background of many simplifiers [e.g. Aarts 1999].

4 The virtues of moderation and material restraint have been promoted, for example, by the Stoics, Buddhists, Christians like St Francis, and other important thinkers like John Ruskin, Henry David Thoreau, and Richard Gregg.
} 
are changing the dominant consumer culture, and they regard voluntary simplicity as 'lifestyle activism' [Hatfield 2011] within a movement of like-minded people ${ }^{5}$ [e.g. Zamwel et al. 2014]. Other scholars emphasise individual forms of the simple lifestyle in which seeking satisfaction through non-material aspects of life plays a key role [see Huneke 2005: 528; Cherrier 2009: 188].

Since the appearance of Duane Elgin's study [1981], understanding the motivations of voluntary simplifiers has become the subject of many other studies that try to find out what underlies a person's decision to reduce consumption. More recently, scholarly attention has focused on analysing the ways in which resistant consumers interpret their behaviour. For instance, Valor's team [2017], drawing on Arendtian and Foucauldian perspectives, has emphasised the role of the individual's perception of power and freedom. They have shown that consumer culture need not be just in opposition to the structures of domination [see Penaloza and Price 1993: 123], but could lie also in freeing oneself by means of self-realisation in an alternative lifestyle ${ }^{6}$ [see Llamas 2016]. The participants in various research studies have reported that environmental problems are the most important factor in their choosing voluntary simplicity [e.g. Alexander and Ussher 2012: 10]. While some authors attribute the adoption of this lifestyle to ideological calls to change the system towards a more sustainable one [e.g. Zamwel et al. 2014], others stress the individualistic aspects of choosing simplicity. For instance, Mary Grigsby [2004: 134] associates people's rejection of the consumerist lifestyle with the personal responsibility of those simplifiers who do not want to be blamed for environmental degradation and who want to have more control over the impact of their lifestyle. A characteristic feature of both these ideological types of motivation is people's reactivity towards consumer culture, a culture which is seen as driving environmental degradation and social alienation.

The fact that the participants in studies dealing with voluntary simplicity have come from countries with relative material abundance has led many authors to the conclusion that the values associated with simplicity appear in connection with (over-)saturation by consumption [e.g. Aarts 1999]. Some authors assume that non-consumption attitudes have emerged due to the failure of consumer societies to fulfil the basic human needs of self-expression and authenticity. These

\footnotetext{
${ }^{5}$ So far, most authors have focused on the collective manifestations of lifestyle change, such as the counter-cultural movement [Zavestoski 2002], the consumer resistance movement [Penaloza and Price 1993], the slow movement [Clark 2008], the culture jammer movement [Lasn 1999], and the voluntary simplicity movement [Alexander and Ussher 2012]. Others have studied specific dimensions of consumption reduction, such as downshifting [Schor 1999], ethical non-consumption [Shaw and Newholm 2002], and various forms of 'consumer rebellion' [Friedman 1999].

${ }^{6}$ Hélène Cherrier [2009] has presented a similar dialectical perspective according to which individuals who seek to change the system express a hero identity through political consumption and those who seek self-expression demonstrate project identity through creative consumption.
} 
authors draw on the psychological theory of Abraham Maslow and emphasise the need to first reach a higher level of material satisfaction in order to have the ability to voluntarily choose simplicity [Zavestoski 2002: 155; Etzioni 2004: 414]. Thus earlier research studies concerned with the phenomenon of voluntary simplicity generally did not anticipate manifestations of it beyond 'Western countries' [see, e.g., Alexander and Ussher 2012; Etzioni 2013]. In post-socialist countries like the Czech Republic, where there had been decades of material shortage, they predicted a rise in consumerism [Etzioni 2013: 9].

Even though studies of non-consumption lifestyles have been conducted relatively rarely in post-socialist countries, the emerging phenomenon of voluntary simplicity has been identified there as well [e.g. Burgiel et al. 2015]. The beginnings of this research on non-consumption lifestyles date back to the period of transformation from state socialism to capitalism in the early 1990s, as we can observe for instance in Librová's longitudinal study ${ }^{7}$ in the Czech Republic. Librová's findings call into question the assumption that non-consumption lifestyles emerge in the context of the experience of material abundance and problematise the broad application of Inglehart's theory. Her research on the modest households ${ }^{8}$ of the families that she called the Colourful ${ }^{9}$ represents the most detailed study in the region and serves as the principal framework for our study, which seeks to find out whether people's motivations to resist consumer culture necessarily depend upon their experience of life in abundance.

The idea behind our research study was simple: we were interested in tackling the question of whether we would be able to find similar families nowadays while applying the same criteria as were applied in Librová's original sample in 1992 (in most cases voluntarily reducing household metabolism and the nonconsumption orientation), and in what would be the main characteristics of these households that were established later, under the conditions of post-revolution-

\footnotetext{
7 The longitudinal research was conducted in three waves in which Librová tried to find people who had voluntarily changed their everyday lifestyle towards less environmentally demanding practices. The first wave of the research took place in 1992. Librová carried out 44 in-depth interviews and observed 47 households with a total of 70 people, whom she video- and tape-recorded. In the second wave of the research in 2002, the sample was limited to the theoretically most compelling cases (and also demographically, due to the death of some of the original respondents) of 15 families, and those were then revisited in the third wave of the research in 2015. In this third wave, additional interviews were conducted with the 21 adult children from these families; for the results, see Pelikán et al. [forthcoming].

8 Although Librová examined lifestyles similar to voluntary simplicity [1999], she has introduced the new term 'voluntary modesty', which better describes the complex nature of such lifestyles [for the related argumentation, see Librová 2008].

${ }^{9}$ Librová called her participants 'the Colourful' not only because of the diverse ways of life they represented, but also because of their more intuitive, non-ideological approach, which was set in opposition to the environmental activist members of the green movement who had modified their lifestyle towards environmental friendliness intentionally [Librová 1994].
} 
ary ${ }^{10}$ capitalism (although it is necessary to note that most of them were still primarily socialised during the period of state socialism). The paper's objective is to explore an alternative mode of voluntary simplicity to the one that currently dominates in the literature [e.g. Alexander and Ussher 2012] and thus to demonstrate the limited reach and validity of the dominant theory.

Theoretically our study builds on Hana Librová's research [1994, 2003; Librová et al. 2016], which is based on three major concepts. Primarily, it draws on the influential concept of post-materialism [Inglehart 1977]. The second theoretical thread was inspired by the categories of new 'luxurious' possessions as outlined by Enzensberger [1996]. These categories of 'new luxury'11 helped Librová define the aspects of the environmentally friendly lifestyle of the households in her sample. Moreover, they enabled her to describe the people's motivations for choosing their lifestyle as well as the benefits that it had brought them on the personal level. The third line of thought in Librová's theoretical underpinnings elaborates more on motivations and connects the categories of 'the good life' with the sociological, psychological, and ethical theories of motivation (deontological, teleological and virtue ethics [Pelikán and Librová 2015; Librová and Pelikán 2016]).

This article is divided into five sections. The following section lays out the context of the research, describing in detail the post-socialist context and especially Hana Librová's research. The third section outlines the methodology used. The fourth section presents our findings in regards to our respondents' motivations for choosing their non-consumption lifestyles. The final, fifth section presents a summary of our findings and discusses the possibility of non-consumption lifestyles emerging without affluence having first been reached.

\section{The research context: post-socialist conditions}

In his essay on the familial reasons for the fall of the Czech socialist regime, Ivo Možný [1991] pointed out the paradoxical relationship of the 'normalisation' period of state socialism (the 1970s and the 1980s) to consumption. ${ }^{12}$ On the one hand,

${ }^{10}$ When we refer to the revolution (hereinafter), we mean the Velvet Revolution in Czechoslovakia (1989): the peaceful overthrow of Czechoslovakia's communist government that led to the economic transformation from a command economy to the free market. When we refer to post-revolution time, we mean the period after 1989.

11 These categories include having enough time and the free will to decide how to fill it; having enough space, which also means being surrounded by fewer things; peace and tranquillity; living in close proximity to nature and in a risk-free, unpolluted environment; and, last but not least, security without the need to fortify or isolate oneself.

12 Možný saw, in a Tocquevillian way, the inability of the old regime to meet the consumption demands and dreams that it itself created as one of the major reasons for the wide-ranging acceptance of the regime's fall and its replacement with a capitalist system [Možný 1993]. 
the regime discursively opposed the 'Western' capitalist culture of abundance connected with deep social inequalities, and on the other hand, it constantly highlighted its own focus on production and the more or less equal distribution of comparable consumer goods [cf. Búriková 2004]. In any case, the scarcity of luxury and even of some basic consumer articles (such as toilet paper and other hygiene products, tropical fruit, and quality meat) became part of widely shared post-socialist narratives and oral histories [Vaněk and Mücke 2016]. The prospects for transforming these socialist realities into some kind of a more equal and less environmentally demanding political and economic regime (in comparison to the image of those in the West) looked promising..$^{13}$ The 'shortage economy' supported the environmentally favourable aspects of the mainstream lifestyle at the time ${ }^{14}$ (such as food self-provisioning and a do-it-yourself culture). However, the popularity of self-provisioning could not be seen as just a coping strategy for the poor [see Jehlička et al. 2013], even though for many families the 1990s was a time of severe austerity, especially for those affected by the structural changes in the economy, and the ability to make do with little was crucial. Búriková compared the old and the new eras based on interviews she conducted on the subject of shopping under socialism and after: 'Whereas under socialism [people] had money but there were not many desirable things in the shops, now [in the 1990s] they feel there is much to be bought but they cannot afford it.' [Búriková 2004: 2] Further, economic growth and the much wider commercialisation of various spheres of life have brought about other cultural and social changes since the fall of the socialist regime ${ }^{15}$ that have improved the material quality of life of Czechs [Večerník 2009], but have widened the social gaps between some parts of society and caused disillusionment in respect to the post-revolutionary idealistic prospect of general affluence.

The specific situation of the post-socialism period ${ }^{16}$ (like the restitution of previously nationalised private property) facilitated a certain lifestyle transfor-

13 This type of hopeful argumentation regarding the non-consumption orientation of ev-
eryday socialist reality was used in academic debates about the potential for post-socialist
development to follow 'a third way' [see Librová 1994]. Smith and Jehlička summed this
up saying, 'mainstream political discourses both within these countries and the EU have
tended to see the trajectory of CEE countries as fixed-locked into a linear temporal and
developmental trajectory towards a Western neo-liberal modernity' [2007: 396].
${ }^{14}$ In addition, socialism stimulated the development of non-authoritarian sub-cultural
movements. The various forms of resistance to socialist consumerism were performed for
example by woodcrafters [Jehlička and Kurtz 2013].
${ }^{15}$ However, in the context of our topic, the demographic, legal, and economic changes are
the most important ones [on the restitution process, see Swain 1999; on changes in repro-
ductive behaviour and family structure, see Mareš and Možný 2005; on housing issues,
among others, see Lux and Mikezsová 2012].
${ }_{16}$ The debate on post-socialist conditions and their regional specifics has resonated in
academic writing in the last few decades-for instance, in the vigorous discussion on the 
mation in the households in Librová's original sample. Her sociological research on modest lifestyles in the Czech Republic nevertheless supports the argument about the tendencies of the socialist path towards consumption, as the participants, who were socialised during the socialist era, often rejected the lifestyle of their (urban and viewed as consumerist) parents and the narratives about their motivations for change were grounded in their admiration for the more or less idealised lifestyle of their grandparents (viewed as being closer to nature, rural, in many cases impacted by the nationalisation of private property and the collectivisation of agricultural land in the post-WWII period). The post-revolutionary years were also marked by the active involvement of the Colourful in local cultural and political life (some held positions in municipal authorities or became mayors). In Bourdieu's terms, they possessed higher social and cultural capital (e.g. wide friendship ties or a university degree, although some of them were experienced autodidacts) and relatively low economic capital (the only exception to this being those who were restituted land and in one case a company) that was accumulated in most of the families in the course of time thanks to their low spending, the success of their small family businesses or the improvement of their position on the labour market in the context of the overall increase in salaries during the last two decades.

For the context of our study it is important that the participants in Librová's research expressed indifference to the increasing consumption, thus differing from the majority. Although the title of Librová's second book, The Half-Hearted and the Hesitant: Chapters on Ecological Luxury [Librová 2003], indicates a shift in the participants' everyday lives towards more mainstream patterns as time went by and towards the aforementioned disenchantment as well, they remained, even after 23 years, more or less faithful to their original motivations, beliefs, and lifestyles [Librová et al. 2016]. Librová wrote, 'the Czech respondents are not guided primarily by environmental intentions. More often, they are led to their lifestyle rather spontaneously by their inner, often Christian, values. Their lifestyle is centred on family and social activities, and they do not enjoy shopping and travelling. Their self-restraint is an unintended and intuitive outcome ... the life of the Colourful Czechs does not conform to the features of the traditional society in that it is not governed by external social pressures' [Librová 1999: 3-5]. The Colourful typically live in a relatively small town or a village (one-third lived in bigger cities) and they have more children than the average Czech family. At the time of the first wave, they were willing to live on one salary, as the mothers stayed at home until the children reached school age and sometimes even engaged in home-schooling, and some downshifted in their jobs or established small, local family businesses.

nature of post-socialism and, more importantly, on the meaning and usefulness of the concept of 'post-socialism' itself [see, e.g., Smith and Stenning 2006; Ferenčuhová 2012; Chelcea and Druțǎ 2016; Hirt et al. 2016]. 


\section{Methodology and analytical procedure}

Methodologically, we reproduced the procedure used in Librová's original study [1994]; for this reason we named our sample 'the New Colourful'. The study had two primary purposes: (1) to investigate what motivates this new generation of Czechs to choose the non-consumption lifestyle; (2) to ascertain how people who have voluntarily reduced consumption in their households interpret specific aspects of their lifestyle. We used the snowball sampling method to obtain an initial set of suggested households, and to this set we applied further theoretical and demographic selection criteria. The final sample of the New Colourful thus constructed consists of 20 households of 36 people (17 males and 19 females). Besides fulfilling the main criteria of low household metabolism and voluntary restraint in terms of consumption, all the participants in our study established their households within the context of post-revolution capitalism in the late 1990s or at the beginning of the new millennium. An important consideration was also the stability of the household, as indicated especially by having started a family or having settled in a particular place. This selection criterion probably resulted in an emphasis on older respondents in the age composition of our sample (they range from 28 to 56 years, $\varnothing 40$, for more detailed information about their basic sociodemographic characteristic see Table 1) - in terms of their age, many of our oldest respondents are close to the youngest ones from the original sample of the Colourful, mainly due to the fact that patterns of starting a family and parenting practices have changed substantially in last 20 years within the second demographic transition [Možný 1993; Mareš and Možný 2005; Rychtaříková 2000].

As can be seen in Table 1, our sample differs in many aspects from the general population. Even though we tried to cover various possible combinations of the basic socio-demographic characteristics in terms of education, type of residence, and profession, we are aware that our sample does not include certain types of households that would definitely deserve our attention-especially single people's households, and more people with lower education or those living in urban environments.

The interviews were about 1.5 or 2 hours long and were video- and taperecorded, and were accompanied by observations in each of the households, including photo-documentation. The topics that were covered were divided into six major clusters: the socio-demographic characteristics of the household; family issues; everydayness and daily routines (work, leisure, hobbies); the consumption and materiality of the household; social relations; and motivations and beliefs (e.g. political, religious, environmental). We also paid special attention to how the respondents perceived the fact that they had been described by the informants as 'voluntarily simple' and to how they themselves saw their distinct economic behaviour. Even though the interviews were partially structured, considerable space was allowed for the communication partners to develop fairly comprehensive biographical narratives and to identify particular sub-topics or accents relevant specifically for their household [Elliott 2005]. 
Table 1. Research sample characteristics-part one

\begin{tabular}{|c|c|c|c|c|c|c|}
\hline \multirow[t]{2}{*}{ Family } & \multirow{2}{*}{\begin{tabular}{l}
\multicolumn{1}{c}{ Age } \\
Male / \\
Female \\
\end{tabular}} & \multicolumn{2}{|c|}{ Education } & \multicolumn{2}{|c|}{$\begin{array}{l}\text { Main occupation at the } \\
\text { time of the interview }\end{array}$} & \multirow[t]{2}{*}{ Housing type } \\
\hline & & Male & Female & Male & Female & \\
\hline 1 & $50 / 41$ & $\begin{array}{l}\text { High } \\
\text { school }\end{array}$ & College & $\begin{array}{l}\text { Ambu- } \\
\text { lance } \\
\text { driver }\end{array}$ & $\begin{array}{l}\text { Physio- } \\
\text { therapist }\end{array}$ & $\begin{array}{l}\text { Secluded wooden } \\
\text { house (owned) }\end{array}$ \\
\hline 2 & $39 / 48$ & $\begin{array}{l}\text { Univer- } \\
\text { sity }\end{array}$ & $\begin{array}{l}\text { Univer- } \\
\text { sity }\end{array}$ & $\begin{array}{l}\text { Doctor - } \\
\text { radiologist }\end{array}$ & $\begin{array}{l}\text { Social } \\
\text { worker }\end{array}$ & $\begin{array}{l}\text { Secluded wooden } \\
\text { house (owned) }\end{array}$ \\
\hline 3 & $28 / 28$ & $\begin{array}{l}\text { High } \\
\text { school }\end{array}$ & $\begin{array}{l}\text { Univer- } \\
\text { sity }\end{array}$ & Fitter & $\begin{array}{l}\text { Materni- } \\
\text { ty/paren- } \\
\text { tal leave }\end{array}$ & $\begin{array}{l}\text { Village terraced } \\
\text { house (rented) }\end{array}$ \\
\hline 4 & $48 / 39$ & $\begin{array}{l}\text { Univer- } \\
\text { sity }\end{array}$ & $\begin{array}{l}\text { Univer- } \\
\text { sity }\end{array}$ & $\begin{array}{l}\text { IT - pro- } \\
\text { grammer }\end{array}$ & $\begin{array}{l}\text { Materni- } \\
\text { ty/paren- } \\
\text { tal leave }\end{array}$ & $\begin{array}{l}\text { Modern solitary } \\
\text { house in village } \\
\text { (owned) }\end{array}$ \\
\hline 5 & $41 / 35$ & $\begin{array}{l}\text { Voca- } \\
\text { tional } \\
\text { course }\end{array}$ & $\begin{array}{l}\text { High } \\
\text { school }\end{array}$ & Craftsman & $\begin{array}{l}\text { Materni- } \\
\text { ty/paren- } \\
\text { tal leave }\end{array}$ & $\begin{array}{l}\text { Village house } \\
\text { (rented) }\end{array}$ \\
\hline 6 & $34 /-$ & $\begin{array}{l}\text { Pri- } \\
\text { mary } \\
\text { school }\end{array}$ & - & Gardener & - & $\begin{array}{l}\text { Solitary house in } \\
\text { village (owned) }\end{array}$ \\
\hline 7 & $52 / 45$ & $\begin{array}{l}\text { Univer- } \\
\text { sity }\end{array}$ & $\begin{array}{l}\text { Univer- } \\
\text { sity }\end{array}$ & Farmer & $\begin{array}{l}\text { Physi- } \\
\text { otherapist }\end{array}$ & $\begin{array}{l}\text { Secluded wooden } \\
\text { house (owned) }\end{array}$ \\
\hline 8 & $46 / 42$ & - & - & Farmer & Farmer & $\begin{array}{l}\text { Secluded wooden } \\
\text { house (owned) }\end{array}$ \\
\hline 9 & $43 / 40$ & $\begin{array}{l}\text { Voca- } \\
\text { tional } \\
\text { course }\end{array}$ & $\begin{array}{l}\text { Univer- } \\
\text { sity }\end{array}$ & $\begin{array}{l}\text { Farmer / } \\
\text { painter }\end{array}$ & $\begin{array}{l}\text { Director of } \\
\text { a mothers' } \\
\text { centre }\end{array}$ & $\begin{array}{l}\text { Secluded wooden } \\
\text { house (owned) }\end{array}$ \\
\hline 10 & $33 / 32$ & $\begin{array}{l}\text { Univer- } \\
\text { sity }\end{array}$ & $\begin{array}{l}\text { Univer- } \\
\text { sity }\end{array}$ & $\begin{array}{l}\text { Farmer / } \\
\text { IT - } \\
\text { graphics }\end{array}$ & Artist & $\begin{array}{l}\text { Secluded wooden } \\
\text { house (owned) }\end{array}$ \\
\hline 11 & $-/ 42$ & - & $\begin{array}{l}\text { High } \\
\text { school }\end{array}$ & - & $\begin{array}{l}\text { Farmer/ } \\
\text { Ginger- } \\
\text { bread } \\
\text { baker }\end{array}$ & $\begin{array}{l}\text { Secluded wooden } \\
\text { house (owned) }\end{array}$ \\
\hline 12 & $38 / 38$ & $\begin{array}{l}\text { Univer- } \\
\text { sity }\end{array}$ & $\begin{array}{l}\text { High } \\
\text { school }\end{array}$ & $\begin{array}{l}\text { Fruit } \\
\text { grower }\end{array}$ & $\begin{array}{l}\text { School } \\
\text { teacher }\end{array}$ & $\begin{array}{l}\text { Village house } \\
\text { (owned) }\end{array}$ \\
\hline 13 & $37 / 41$ & $\begin{array}{l}\text { Univer- } \\
\text { sity }\end{array}$ & $\begin{array}{l}\text { Univer- } \\
\text { sity }\end{array}$ & $\begin{array}{l}\text { Coach, ex- } \\
\text { periential } \\
\text { pedagogy }\end{array}$ & $\begin{array}{l}\text { Maternity } \\
\text { leave/ } \\
\text { Nutrition } \\
\text { consultant }\end{array}$ & $\begin{array}{l}\text { Town, apartment } \\
\text { (owned) }\end{array}$ \\
\hline
\end{tabular}


Table 1. Research sample characteristics-part two

\begin{tabular}{|c|c|c|c|c|c|c|}
\hline \multirow[t]{2}{*}{ Family } & \multirow{2}{*}{$\begin{array}{c}\text { Age } \\
\text { Male / } \\
\text { Female } \\
\end{array}$} & \multicolumn{2}{|c|}{ Education } & \multicolumn{2}{|c|}{$\begin{array}{l}\text { Main occupation at the } \\
\text { time of the interview }\end{array}$} & \multirow[t]{2}{*}{ Housing type } \\
\hline & & Male & Female & Male & Female & \\
\hline 14 & $36 / 39$ & $\begin{array}{l}\text { Univer- } \\
\text { sity }\end{array}$ & $\begin{array}{l}\text { Univer- } \\
\text { sity }\end{array}$ & $\begin{array}{l}\text { Electrical } \\
\text { engineer }\end{array}$ & $\begin{array}{l}\text { Project } \\
\text { coordina- } \\
\text { tor NGO }\end{array}$ & $\begin{array}{l}\text { Town, apartment } \\
\text { (owned) }\end{array}$ \\
\hline 15 & $38 / 37$ & $\begin{array}{l}\text { Univer- } \\
\text { sity }\end{array}$ & $\begin{array}{l}\text { Univer- } \\
\text { sity }\end{array}$ & $\begin{array}{l}\text { Social } \\
\text { scientist }\end{array}$ & $\begin{array}{l}\text { Director of } \\
\text { alternative } \\
\text { kindergar- } \\
\text { ten }\end{array}$ & $\begin{array}{l}\text { Town, apart- } \\
\text { ment (owned by } \\
\text { parents) }\end{array}$ \\
\hline 16 & $35 / 28$ & $\begin{array}{l}\text { Univer- } \\
\text { sity }\end{array}$ & $\begin{array}{l}\text { Univer- } \\
\text { sity }\end{array}$ & $\begin{array}{l}\text { Software } \\
\text { developer }\end{array}$ & $\begin{array}{l}\text { School } \\
\text { teacher }\end{array}$ & $\begin{array}{l}\text { Small town, house } \\
\text { (owned) }\end{array}$ \\
\hline 17 & $38 / 38$ & $\begin{array}{l}\text { Univer- } \\
\text { sity }\end{array}$ & $\begin{array}{l}\text { Univer- } \\
\text { sity }\end{array}$ & $\begin{array}{l}\text { Leisure } \\
\text { instructor }\end{array}$ & $\begin{array}{l}\text { Leisure } \\
\text { instructor }\end{array}$ & $\begin{array}{l}\text { Town, apartment } \\
\text { (owned) }\end{array}$ \\
\hline 18 & $37 / 37$ & $\begin{array}{l}\text { Univer- } \\
\text { sity }\end{array}$ & $\begin{array}{l}\text { Univer- } \\
\text { sity }\end{array}$ & $\begin{array}{l}\text { Leisure } \\
\text { instructor }\end{array}$ & $\begin{array}{l}\text { Maternity } \\
\text { leave/ } \\
\text { parental } \\
\text { leave }\end{array}$ & $\begin{array}{l}\text { Small town, fam- } \\
\text { ily house (rented) }\end{array}$ \\
\hline 19 & $37 / 33$ & $\begin{array}{l}\text { High } \\
\text { school }\end{array}$ & $\begin{array}{l}\text { High } \\
\text { school }\end{array}$ & $\begin{array}{l}\text { Removal } \\
\text { man }\end{array}$ & $\begin{array}{l}\text { Maternity } \\
\text { leave/ } \\
\text { parental } \\
\text { leave }\end{array}$ & Cottage (owned) \\
\hline 20 & $57 / 54$ & $\begin{array}{l}\text { Univer- } \\
\text { sity }\end{array}$ & $\begin{array}{l}\text { Univer- } \\
\text { sity }\end{array}$ & $\begin{array}{l}\text { Building } \\
\text { construc- } \\
\text { tion tech- } \\
\text { nician }\end{array}$ & $\begin{array}{l}\text { Account- } \\
\text { ant }\end{array}$ & $\begin{array}{l}\text { Small town, fam- } \\
\text { ily house (owned) }\end{array}$ \\
\hline
\end{tabular}

Note: Missing values represent information that was not relevant or was not provided by the participants.

The interviews were transcribed and analysed in several steps. As only two of the three researchers took part in each interview, we began with the collaborative writing of rich field notes after every visit. This phase was followed by individually listening to the recordings and line-by-line reading of the transcripts. We then combined the results of the individual analysis of the major topics from the interviews with the most telling pictures of the households, and we worked together in meetings, analysing the collected information and using visualisation and paper-and-pen technique to triangulate the findings from the individual readings. This way, we were able to collate the structured topics from each interview as well as discuss those that emerged newly in the field. Subsequently, we wrote and cross-commented memos and created the first analytical report. 
The applied analytical technique followed the interpretive analysis inspired by grounded theory [Charmaz 2006], while also applying some procedures to increase the reflection in the teamwork [Barry et al. 1999].

\section{The New Colourful: diverse ways of practicing voluntary simplicity}

When the New Colourful couples were making the decision about their lifestyle, the discussion about whether to live in the city or in the countryside was of central importance. For 12 of the 20 households, this discussion led to moving to the countryside. Living in the city was incompatible with their idea of the good life. When we asked about the motivations for the departure, we often received well-thought-out answers. ${ }^{17}$ We also heard stories referring to various problems caused by city life, or rather attributed to city dwelling, and to the need for freedom which could not be fulfilled in the city. In their reasoning of why they chose the country, the respondents often mentioned the clean environment, the children's well-being, and their desire for a 'true' or an 'examined' kind of life. ${ }^{18}$

I always remember how I didn't want to wash my hands when we got back, so that I could keep at least something from the genuine life with me. It seemed true, tangible. How the milk spurted from the cow. ... When our daughter was born, we decided that she wouldn't spend her childhood in Prague, that's nonsense. (Family 9 , female, 40)

While most of the participating families decided to move to the countryside, nearly half of the families who decided to stay in the city explained their choice using economic as well as environmental ${ }^{19}$ and family reasons. According to their statements, both of these groups focus on truly fulfilling experiences in their everyday lives. Both of them believe that thanks to the choice of residence they have made, they have more space for themselves and their family. The city-based interviewees assert that they also get to go outdoors into nature more often this way as they do not have to take care of a house and a farm. For instance, the reasons Family 14 gave for choosing to live in a block of flats on the outskirts of Prague are

\footnotetext{
${ }_{17}$ We identified four residential motives among the people who had moved to the countryside: the distaste for life in the city, the desire to live a pleasant life, the desire to live in freedom, and the desire to return to one's roots [Kala et al. 2016].

${ }_{18}$ Similar reasoning is used by the participants in counterurbanisation research in the Czech Republic [e.g. Šimon 2014: 131].

${ }^{19}$ In the city, there is no need to own a car, and there are lower energy costs and better access to services such as farmers' markets, second-hand shops, or nature preschools. Philosopher Erazim Kohák [see Mráčková et al. 2014: 62-63] is a well-known proponent of the thought that living in a city, ideally in dense housing development, is an expression of an environmentally-friendly attitude.
} 
in fact similar to the reasons cited by those who decided to move to the country. The search for the best possible quality of life for the children was ultimately the most important factor:

For a while we thought we would move somewhere outside the city. We kept debating the pros and cons. And in the end, it was this block of flats that won.... We were more interested in devoting ourselves to family life rather than working on a house somewhere. (Family 14, female, 39)

We assume that devotion to family life results in various lifestyles that are all seen by our respondents as 'low consumption' lifestyles. It cannot be said that our respondents have somehow given up on consumerism. It is rather that their lifestyle excludes consumerism because of other priorities. In their statements we find a mistrust of the assumption that acquiring more material goods could make their lives better. Thus the New Colourful realise, like Enzensberger [1996], that the very physical conditions of human existence (like nature, space, time, attention, silence, and safety) have become luxuries and that, in order to enjoy them, require a person to practice self-restraint in terms of consumption, career, etc. A common view among the interviewees is that their deliberate choice of consumption reduction has brought them benefits in return, such as improvement in various aspects of their everyday life-what Librová has called 'ecological luxury' [2003].

A recurrent theme in the interviews is the respondents' conviction that a person's quality of life is relatively more important than their job and the ability to spend money on things. Talking about this issue, one interviewee said:

Other families put their money, for instance, into vacations, expensive, exotic vacations. We put our money into schools, into daily life. But that is what is important to me. To scrimp and suffer all year to save for plane tickets for a two-week vacation abroad doesn't make sense to me. We should live in the now. (Family 15, male, 38)

This view was echoed by other respondents who prefer to spend more time caring for their children and gaining non-materialistic satisfaction, rather than rushing around to gain material satisfaction. ${ }^{20}$

The New Colourful, as we gathered from their statements, seek to find a balance between self-restraint and their life expectations. They claim to have no understanding of conspicuous consumption and spending money on material 'status goods' like expensive cars or houses. However self-stylising it may be, they stress that their focus is on a high standard' in daily consumption. For in-

20 The way in which they speak about their investments in daily life is comparable to the downshifters' lifestyle as described, for example, by Schor [1999]. 
stance, Family 16 cut down on transport costs and spends more money instead on 'health food products'.

We save quite a lot also by not having a car. It may not seem like it, but that in itself makes quite a difference. We don't go out drinking, either. On the other hand, what we save, we then spend on shopping in health food stores where we buy more expensive things. (Family 16, male, 35)

His wife also appreciates being able to avoid animal ingredients in their kitchen, which has brought them the pleasure of discovering new cuisines. 'We enjoy the possibilities that have opened up by not buying meat or cheese. We have found plenty of flavours and options for cooking.' (Family 16, female, 28)

When we consider all this together, we can assume that voluntary self-restraint lets people fulfil their idea of a happy life. This is clearly demonstrated among the respondents by their not owning or only occasional use of a car. However, there are only six totally car-free households in our sample; more often our respondents make just limited use of their car, and many of them emphasise the pleasure of other modes of transport. One commented that: 'I find it pleasant to walk to the station in the fresh air. It would feel unnatural for me drive from home to work.' Family 16 (female, 28) Another family, Family 8, got a car when they were renovating their house. However, due to pressure from their children, they soon got rid of it. Using this comfortable transportation meant that, as a family, they had lost the leisurely, long periods of time when they would walk home from town together through the open landscape. Thus giving up the car was not inspired by any ideology, as Family 8 (male, 46) explains, but essentially by a desire to live a happier life [cf. Schor 1999].

This theme of voluntary self-restraint in the area of car use came up for example in discussions of consumption reduction, in which we were particularly interested. The car is perceived as one of the driving forces of excessive consumption. The decision-making process concerning car use is a reflection of a conscious discussion about what form of lifestyle one desires. A low-consumption lifestyle could be indirectly based on not owning a car, as Family 5 described to us. When people have to carry their purchases by hand, naturally the number of goods they purchase will be limited, which can also be seen as a benefit.

We had just borrowed a car from my brother. We enjoyed the luxury. So I said to myself, 'we need to return it soon, it would be easy to get used to this.' To go shopping and not worry that I can't get something because it's heavy. Not weigh my priorities, what I can put in my back-pack. (Family 5, female, 35)

The New Colourful usually do not think of the limitations on some kinds of consumption as limitations because they have deliberately decided for self-restraint. In their households, this decision is manifested in not owning certain appliances. 
Many appliances that are otherwise quite commonly used are absent (like dryers, electric tea kettles, and microwaves). They often explained their dislike of these appliances by observing that they get the work done 'unnaturally fast'. While the respondents generally welcome technologies that save hard labour (tractors, power saws, etc.), machines that save only time are seen by many as unnecessary. An iconic example of this is represented by attitudes towards dishwashers, which had become a topic for negotiation in most of the households that we examined. Washing dishes by hand plays an important role for the New Colourful; it is a way to relax, sometimes an opportunity to warm up one's hands in a frugally heated house, and a chance for the kids to do meaningful work. According to many respondents' statements, they take pleasure in washing the dishes by hand. For these reasons almost none of our respondents had purchased a dishwasher.

The key to thriftiness, according to the accounts of the New Colourful, is to reflect on whether certain expenses are really necessary. Their frugality is mainly about the state of mind, as they report. In the interviews, there often appear statements about having enough; 'If I don't have it, I don't need it' is the motto of Family 14 (male, 36). They are aware of how uncommon their belief that they do not need more is, and they feel that they have to defend being content with the little they have:

I don't feel like I'm totally different. I may have a smaller house than most people. But I actually prefer that. It's not that I'd feel a lesser person somehow, because I have less of something. I feel good, have enough of everything. (Family 1, female, 41)

The New Colourful basically resist the culture of debt. Even if they could borrow money for immediate consumption, the feeling of being in debt would bother them. Hence, consumer loans and mortgages practically do not appear in our sample. To our surprised inquiries about how they got the money to furnish or build their homes, many answered in a manner similar to Family 2 (male, 39):

\begin{abstract}
When you live in such a way that you don't want to throw away things that still work, you've been riding the same bike since you were fifteen because it's still good, you don't eat out, don't go on expensive vacations, then what? You can put your money into housing ...
\end{abstract}

In this respect the New Colourful clearly follow the old-fashioned approach of delayed consumption. As one interviewee summed it up: 'When we need to save, we simply economise.' (Family 19, male, 37)

Thriftiness offers the New Colourful a kind of freedom ${ }^{21}$ and debt-free liv-

${ }^{21}$ The previous study reported that some consumers crave to liberate themselves from the norms and restrictions dictated by the forces of the market, and the idea of freedom from social constraints is perceived by them as luxury [Llamas 2016]. 
ing. They appreciate mainly the opportunity to slow down when they need it, and the independence of their life choices in regards to leaving their job. The absence of debt, the existence of savings, and their self-sufficiency allow our participants to rethink their attitudes to work. Like Huneke's [2005] respondents, one of the New Colourful said: 'We are in the phase of life when free time is a lot more important than money.' Without knowing the guidelines for a simpler and happier life, they use the advantage of knowing how to manage with little to reduce their workload. In this context, in the interviews we again came across the New Colourful setting themselves apart from the mainstream practice:

The way I do everything is I do the opposite of what others are doing. I save when others are spending, and I spend when others are saving. I'm not at all interested in some crises and other nonsense. I wait for an opportunity. There was a year when I only worked two months. Usually I work less than half a year. (Family 5, male, 43)

Interviewer: Is this because you spend less, rather than making a lot?

I don't think so. You know how it is? When you want something, the more you go after it, the more it escapes you. Guys scramble to get work, to work as much as possible, but then they are cheap or can't keep up, and then they have to spend more because they can't keep up. It's better to lie low and wait, until you just snap your fingers and it falls in your lap. (Family 5, male, 43)

We observed a kind of luxurious self-restraint also when the interviews touched on the topic of one's career. The New Colourful put more emphasis on having a job that is satisfying than on earnings. For example, when the wife in Family 2 (female, 48), a social worker, went back to work after parental leave, 'money was not the motivation at all. We would have been able to live quite comfortably on one salary', she said. They prefer meaningful work to profit and prestige. Work is more a calling than a money-making endeavour, as demonstrated by the following statement from Family 9 (female, 40), a director of a maternity centre who sometimes works without remuneration: 'I do what I feel I am supposed to be doing. I don't care if I have money or not at the moment. It will work out one way or another; in the end I always have some.' Thanks to their meaningful work, the New Colourful feel liberated from questions such as 'What shall I do today? What should I get started on? What to do with myself?', as was explicitly expressed by Family 7 (male, 52), who were caring for a thousand-head flock of sheep. On this issue, the wife said: 'simple work has added value because it welds us together'. (female, 45) Our interviewees greatly appreciate the opportunity to be more with their family thanks to their self-restraint in their career [cf. Huneke 2005].

When asked about their interpretation of the origins of their lifestyle, the participants talked about the influence of their families. Sometimes, as in the case of Family 9 (female, 40), they were motivated negatively to live differently from their parents. She remembers that she "was always in an enclosed space" (in school, in an after-school club) and she decided to live differently in her adult- 
hood, and to 'be present in the children's upbringing'. However, more often the New Colourful have reproduced the modest lifestyle of their families:

My parents were 'working intelligentsia' during communism. The work was nothing special. We had nothing, just a lot of books in a house that was falling on our heads. But when you grow up in these conditions, you are fine. My parents never took it as a tragedy. They always said, 'Well, there are other things that it's necessary to concentrate on. Property is not worth it. Let's read or do some mental work. We will not cry about not having a car.' ... After the revolution, my father started to do business and he was doing well. Suddenly we had one car, then another one, even better. I was already at the grammar school when our life's journey split up quite a bit. They've taught me something that I am currently practicing. But they live in a completely different way; they have the property and the Audi. (Family 14, female, 39)

The analysis of the interviews has shown that the New Colourful who grew up in less affluent families with higher cultural capital and a positive approach to a modest life have relatively successfully reproduced the lifestyle of their parents. ${ }^{22}$ These findings call into question Inglehart's theory and rather support those who have criticised it, drawing on Bourdieu's theory of habitus. ${ }^{23}$ While authors like Etzioni [2013] report over-saturation with consumption as the main motive for choosing the voluntarily simple lifestyle, most of the New Colourful, like the original Colourful [Librová 2003], based their argumentation more on aesthetic considerations or sometimes on habit. Even though the respondents' interpretations of choosing a non-consumption lifestyle ${ }^{24}$ vary, we have identified several features that they have in common. The New Colourful seek personal integrity and wnat their values and lifestyle to be in harmony, and voluntary self-restraint helps them achieve this. Therefore, they perceive certain aspects of their own simplicity as luxury, as something that enriches them. The New Colourful interpret their life paths as a result of a gradual transformation of their lifestyle based on their faithfulness to their values, not as a radical lifestyle transformation, like in the case of the 'back to the land movement' [see Elgin 1981: 20] or the 'simplicity movement' [see Alexander and Ussher 2012: 8]. Overall, these findings suggest

\footnotetext{
${ }^{22}$ The other research findings of our team, regarding the relatively successful intergenerational reproduction of the Colourful's habitus to their children, suggest that higher cultural capital could facilitate the reproduction of a modest way of life [for more on these results, see Pelikán et al. 2017].

${ }^{23}$ Bourdieu understands habitus as a nonlinear process, which, while being anchored in class, also grows out of imitation and one's personal experience, thus opposing, with regard to consumption, the perspective of homo oeconomicus [1984: 183].

${ }_{24}$ We deliberately use the term non-consumption lifestyle because our participants did not identify with the designation voluntary simplicity; however, they have the same characteristics.
} 
that their motivations are not teleological (in order to change the system, to help the global environment, etc.), but rather deontological (because of their values, life experience, or tradition) [cf. Pelikán and Librová 2015].

\section{Discussion and conclusion}

The objective of this paper was to present an alternative mode of voluntary simplicity which continuously exists in the Czech post-socialist context. Although the motivations of New Colourful seem to be consistent with the motivations of other complementary research studies' participants, ${ }^{25}$ they did not change their lifestyle while living in affluence. The empirical findings in this study problematise the link between a person's lifestyle choice and materialism. The principal theoretical implication of this study is that our findings call into question Inglehart's structural presupposition that non-consumerist lifestyles like voluntary simplicity develop within affluent environments. The findings of this investigation complement those of earlier studies that identified aspects of lifestyle simplification also within economically less affluent environments and societies [Burgiel et al. 2015; Librová 1994; Zaritska 2015].

This research extends the existing knowledge about people's motivations for choosing non-consumerist lifestyles. The findings reported above suggest that the voluntary self-restraint of the participants in our study has brought them diverse benefits, like having sufficient time and peace of mind, feeling safe, living in close proximity to nature, having a garden, and having access to clean water and healthy food, which could be classed as 'ecological luxury' [cf. Librová 2003]. Typically, the New Colourful have a tendency to go 'back to the land' (or at least they consider it a realistic option), and they follow more traditional ways of life (e.g. home-schooling, self-sufficiency). Taking into consideration that people pursue 'simple lifestyles' with or without having obtained affluence, we assumed that there must be another explanation. Inspired by Bauman's critique of the post-modern version of yearning for the 'great simplification' and by $\mathrm{Li}$ brová's study of the cultural stereotype of simplicity ${ }^{26}$ [2008], we presuppose that the roots of simple lifestyles could also lie in a person's dissatisfaction with the promise of modernity, a promise suggesting that it is possible to gain and lead

\footnotetext{
${ }^{25}$ The New Colourful adopt a non-consumerist lifestyle for reasons similar, for instance, to those of Schor's study participants-'more time, less stress, and more balance in life', 'more time to spend by caring for children', and 'a more meaningful life' [1999: 138]. Schor [1999] and other authors [e.g. Craig-Lees, Hill 2002] emphasise that downshifters or simplifiers have experienced a change in their lifestyle from over-work and over-consumption to a lifestyle based on post-materialistic values.

${ }^{26}$ Librová [2008] proposed nine dimensions of the stereotypical view of simplicity: non-ownership, lack of power, aesthetics, thoughtful behaviour, naturalness, freedom of movement, the sedentary life/faithfulness to a place, and living lightly.
} 
the good life through material abundance. Therefore, it appears that the cultural prototype of free and happy peasants has been rediscovered both in the affluent West and in post-socialist countries where the ideas of modernity have been also prevalent [cf. the paradoxical relationship of state socialism to consumption in Možný [1991, 1993]. The conclusions of authors like Zavestoski [2002] and Etzioni [2004, 2013] do not seem to be completely valid; their application of Maslow's hierarchy to the interpretation of motivations for choosing simplicity may be misleading or at least of limited usefulness. The New Colourful had not first attained true affluence. They decided for a non-consumption lifestyle because they realised that their vision of the good life could not be fulfilled through consumption. Our findings thus further support Huneke's [2005: 544] the idea that voluntary simplicity is not reserved for affluent people, and that it can be relevant also for those whose basic needs are less well satisfied. However, this is an important issue in need of future research.

The modest lifestyle of the New Colourful emerges from their specific socio-cultural capital, which allows them to shape their lifestyle to fit their desires, not as a reaction against the pervasive consumer-driven culture [cf. Grigsby 2004: 64; Zavestoski 2002: 151]. In line with Librová's [1999], Huneke's [2005: 544], and Craig-Lees and Hill's findings [2002: 191], we believe that non-materialistic and non-consumerist values may not be the main driving factors behind people choosing the voluntarily simple lifestyle. Many authors describe voluntary simplicity as a countercultural movement of people 'who are resisting high consumption lifestyles' [Alexander and Ussher 2012: 1] and consider voluntary simplifiers to be 'cultural change agents' [Grigsby 2004: 86]. In contrast to such a view, the New Colourful do not see themselves as members of any movement. Moreover, they often say that, actually, they do not live simply. They are aware that it would be easier to live the mainstream way, but that 'wouldn't bring them joy', as we heard many times in the interviews. They limit their consumption as part of a lifestyle trade-off. According to our findings, the New Colourful do not see their lifestyle as something deviating from culture, but rather as a true manifestation of it. They are trying to fulfil certain pre-existing cultural ideals (like living close to nature in a family house), but they are using different ways to achieve them.

Our findings suggest that the Czech socialist past created conditions suitable for the formation of a non-ideological and primarily self-oriented version of voluntary simplicity. The New Colourful, both in the city and in the countryside, seek to find a place where they can express their self-identity and 'authenticity' outside of the mainstream consumerist system [cf. Smith and Jehlička 2007]. Some of their activities just follow in the tradition of self-provisioning, barter exchange and 'do it yourself' culture, which helped the generation of their parents cope while living in the socialist system of central provisioning. Their other activities, like running independent maternity centres, kindergartens and schools, respond to current social needs. Thus the New Colourful are not interested in 'dropping out' of society, they are creating space for safe and independent activ- 
ities similarly to what many people did in the period of state socialism [cf. Smith and Jehlička 2007]. The interviews revealed that a solid foundation in the form of debt-free real estate and also their know-how regarding making a living 'outside of the system' provide the participants in our study with a sense of security and the freedom to meet their life goals.

While the original Colourful chose to follow the path of voluntary simplicity in the context of relatively poor socialist (or early-capitalist) Czechoslovakia, the New Colourful, for the most part, made their decision in a period of advanced capitalism. Despite this generational difference, the two samples show marked similarities, especially in the area of motives and in relation to consumerism. This combination of our findings provides some support for the conceptual premise that non-consumerist (environmentally friendly, sustainable) lifestyles can be formed also in societies with relatively less material abundance. Therefore, we can assert that this particular form of Czech voluntary simplicity was not just an ephemeral phenomenon of the early 1990s.

LUKÁš KALA is a sociologist working in the fields of the sociology of lifestyles and rural sociology. His research focuses mainly on the environmental aspects of lifestyles. His previous publications challenge the stereotype that the lifestyle of people who live single is environmentally unfriendly.

VojtĚCH PeLIKÁN is a doctoral candidate in environmental humanities at Masaryk University. His research interests include environmental anthropology, environmentally friendly lifestyles and environmental movements.

Lucie GaLČAnOvá is a researcher in the Office for Population Studies at Masaryk University. Her research interests include housing and urban studies with focus on home and domesticity, and cultural and spatial aspects of population ageing.

\section{References}

Aarts, W. 1999. De status van soberheid. Een onderzoek naar status en milieu. (The Status of Voluntary Moderation: A Study on Status and Environmentally Induced SelfRestraint) PhD Thesis, Amsterdam: University of Amsterdam. Retrieved 22 July 2017 (https://pure.uva.nl/ws/files/2251733/108399_UBA003000147.pdf).

Alexander, S. 2011. 'The Voluntary Simplicity Movement: Reimagining the Good Life Beyond Consumer Culture.' International Journal of Environmental, Cultural, Economic and Social Sustainability' 7. Retrieved 22 July 2017 (http://simplicityinstitute.org/wp-content/uploads/2011/04/ IntroductionToVoluntarySimplicity.doc.pdf).

Alexander, S. and A. McLeod. (eds) 2014. Simple Living in History: Pioneers of the Deep Future. Sydney: Simplicity Institute Publishing. 
Alexander, S. and S. Ussher. 2012. 'The Voluntary Simplicity Movement: A MultiNational Survey Analysis in Theoretical Context.' Journal of Consumer Culture 12 (1): 66-86, https:/ / doi.org/10.1177/1469540512444019.

Barry, C. A., N. Britten, N. Barber, C. Bradley and F. Stevenson. 1999. 'Using Reflexivity to Optimize Teamwork in Qualitative Research.' Qualitative Health Research 9 (1): 26-44, https://doi.org/10.1177/104973299129121677.

Bourdieu, P. 1984. Distinction: A Social Critique of the Judgement of Taste. London: Routledge \& Kegan Paul.

Burgiel, A., I. Sowa and J. Zrałek. 2015. ‘Voluntary Simplicity-Sustainable Alternative to Overconsumption.' Polityki Europejskie, Finanse i Marketing 13 (62): 18-29.

Búriková, Z. 2004. 'Consuming Socialism: Domesticated Socialist Shops in the Slovak Village.' Pp. 1-14 in Thinking Together. Proceedings of the IWM Junior Fellows' Conference, Winter 2003, edited by A. Cashin and J. Jirsa. Vienna: IWM Junior Visiting Fellows' Conferences, Vol. 16.

Charmaz, K. 2006. Constructing Grounded Theory: A Practical Guide Through Qualitative Analysis. London, Thousand Oaks, CA, and New Delhi: Sage.

Chelcea, L. and O. Druță. 2016. 'Zombie Socialism and the Rise of Neoliberalism in Post-Socialist Central and Eastern Europe.' Eurasian Geography and Economics 57 (4-5): 521-544, https://doi.org/10.1080/15387216.2016.1266273.

Cherrier, H. 2009. 'Non-consumption Discourses and Consumer-Resistant Identities.' Journal of Business Research 62 (2): 181-190, https://doi.org/10.1016/j.jbusres.2008.01.025.

Clark, H. 2008. 'SLOW+ FASHION-an Oxymoron-or a Promise for the Future...?.' Fashion Theory 12 (4): 427-446, https://doi.org/10.2752/175174108X346922.

Craig-Lees, M. and C. Hill. 2002. 'Understanding Voluntary Simplifiers.' Psychology and Marketing 19 (2): 187-210, https://doi.org/10.1002/mar.10009.

Elgin, D. 1981. Voluntary Simplicity. Toward a Way of Life That Is Outwardly Simple, Inwardly Rich. New York: Harper.

Elliott, J. 2005. Using Narrative in Social Research. Qualitative and Quantitative Approaches. London: Sage, https://doi.org/10.4135/9780857020246.

Enzensberger, H. M. 1996. 'Reminiszenzen an den Überfluss.' Spiegel 51: 108-118.

Etzioni, A. 1998. 'Voluntary Simplicity: Characterization, Select Psychological Implications, and Societal Consequences.' Journal of Economic Psychology 19 (5): 619-644.

Etzioni, A. 2004. 'The Post Affluent Society.' Review of Social Economy 62 (3): 407-420, https://doi.org/10.1080/0034676042000253990.

Etzioni, A. 2013. Essays in Socio-economics. Berlin: Springer.

Ferenčuhová, S. 2012. 'Urban Theory beyond the "East/West Divide"? Cities and Urban Research in Postsocialist Europe.' Pp. 65-74 in Urban Theory beyond the West: A World of Cities, edited by T. Edensor and M. Jayne. London and New York: Routledge.

Friedman, M. 1999. Consumer Boycotts: Effecting Change through the Marketplace and the Media. London: Routledge.

Grigsby, M. 2004. Buying Time And Getting By: The Voluntary Simplicity Movement. Albany, NY: SUNY Press.

Hatfield, K. 2011. Voluntary Simplicity: Lifestyle Activism in Late Modernity. Master's thesis, School of Journalism and Communication, Carleton University, Ottawa.

Hirt, S., S. Ferenčuhová and T. Tuvikene. 2016. 'Conceptual Forum: The "Post-Socialist" City.' Eurasian Geography and Economics, 57 (4-5): 497-520, https://doi.org/10.1080/15387216.2016.1271345. 
Huneke, M. E. 2005. 'The Face of The Unconsumer: An Empirical Examination of the Practice of Voluntary Simplicity in the United States.' Psychology \& Marketing 22 (7): 527-550, https://doi.org/10.1002/mar.20072.

Inglehart, R. 1977. The Silent Revolution: Changing Values and Political Styles among Western Publics. Princeton, NJ: Princeton University Press.

Inglehart, R. 1990. The Culture Shift in Advanced Industrial Society. Princeton, NJ: Princeton University Press.

Iwata, O. 2006. 'An Evaluation of Consumerism and Lifestyle as Correlates of a Voluntary Simplicity Lifestyle.' Social Behavior and Personality: An International Journal 34 (5): 557-568, https://doi.org/10.2224/sbp.2006.34.5.557.

Jehlička, P. and M. Kurtz. 2013. 'Everyday Resistance in the Czech Landscape: The Woodcraft Culture from the Hapsburg Empire to the Communist Regime.' East European Politics and Societies 27 (2): 308-332, https://doi.org/10.1177/0888325413483550.

Jehlička, P., T. Kostelecký and J. Smith. 2013. 'Food Self-provisioning in Czechia: Beyond Coping Strategy of the Poor: A Response to Alber and Kohler's "Informal Food Production in the Enlarged European Union".' Social Indicators Research 111 (1): 219-234, https://doi.org/10.1007/s11205-012-0001-4.

Kala, L., L. Galčanová and V. Pelikán. 2016. 'Residential Preferences in the Context of Voluntary Simple Lifestyles: What Motivates Contemporary Czech Simplifiers to Reside in the Countryside?' Human Affairs 26 (4): 410-421, https://doi.org/10.1515/humaff-2016-0035.

Lasn, K.1999. Culture Jam: How to Reverse America's Suicidal Consumer Binge-And Why We Must. New York: William Morrow.

Lee, M., D. Roux, H. Cherrier and B. Cova. 2011. 'Anti-Consumption and Consumer Resistance: Concepts, Concerns, Conflicts and Convergence.' European Journal of Marketing 45 (11/12), https://doi.org/10.1108/ejm.2011.00745kaa.001.

Librová, H. 1994. Pestři a zelení: kapitoly o dobrovolné skromnosti. (The Colourful and the Green: Chapters on Voluntary Simplicity) Brno: Veronica and Hnutí Duha.

Librová, H. 1999. 'The Disparate Roots of Voluntary Modesty.' Environmental Values 8 (3): 369-380, https://doi.org/10.3197/096327199129341879.

Librová, H. 2003. Vlažní a váhaví: kapitoly o ekologickém luxusu. (The Half-Hearted and the Hesitant: Chapters on Ecological Luxury) Brno: Doplněk.

Librová, H. 2008. 'The Environmentally Friendly Lifestyle: Simple or Complicated?' Sociologický časopis/Czech Sociological Review 44 (6): 1111-1128.

Librová, H. and V. Pelikán. 2016. 'Ethical Motivations and the Phenomenon of Disappointment in Two Types of Environmental Movements: Neo-Environmentalism and the Dark Mountain Project.' Environmental Values 25 (2): 167-193, https://doi.org/10.3197/096327116X14552114338828.

Librová, H., V. Pelikán, L. Galčanová and L. Kala. 2016. Věrní a rozumní: kapitoly o ekologické zpozdilosti. (The Faithful and the Reasonable: Chapters on Ecological Foolishness) Brno: Masarykova univerzita.

Llamas, R. 2016. 'Is Freedom the New Luxury? A Contemporary Consumer Perspective.' Pp. 2-17 in 14th International Marketing Trends Conference. Venice: Paris-Venice Marketing Trends Association. Retrieved 22 July 2017 (http://www.marketing-trends-congress. com/archives/2016/pages/PDF/LLAMAS.pdf).

Lux, M. and M. Mikeszová. 2012. 'Property Restitution and Private Rental Housing in Transition: The Case of the Czech Republic.' Housing Studies 27 (1): 77-96, https://doi.org/10.1080/02673037.2012.629643.

Mareš, P. and I. Možný. 2005. 'The Czech Family, Reproductive Behaviour, and the Value of Children in the Czech Republic.' Pp. 67-90 in The Value of Children in Cross-cultural 
Perspective. Case Studies from Eight Societies, edited by G. Trommsdorff and B. Nauck. Lengerich: Pabst Science Publishers.

Možný, I. 1991. Proč tak snadno...: některé rodinné důvody sametové revoluce. (Why So Easy ... :

Some Familial Causes of the Velvet Revolution) Prague: Sociologické nakladatelství.

Možný, I. 1993. 'The Czech Family in Transition from Social to Economic Capital.'

Sborník prací Filozofické fakulty brněnské univerzity. C, Řada historická (41-42): 7-14.

Mráčková, M., B. Šimonová and V. Vejvoda. (ed.) 2014. Legenda o sídlišti. (Housing Estate Legend) Prague: Akademie výtvarných umění.

Myers, D. G. 2003 ‘Wealth and Happiness: A Limited Relationship.' Pp. 41-52 in Voluntary Simplicity: Responding to Consumer Culture, edited by D. Doherty and A. Etzioni. Lanham: Rowman \& Littlefield.

Pelikán, V. and H. Librová. 2015. 'Motivation for Environmental Direct Action in the Czech Republic: The Case of the 2011 Blockade at the Šumava National Park.' Sociální Studia / Social Studies 12 (3): 27-52.

Pelikán, V., L. Galčanová and L. Kala. 2017. 'Ecological Habitus Intergenerationally Reproduced. The Children of Czech "Voluntary Simplifiers" and Their Lifestyle.' Journal of Consumer Culture 0 (0): 1-21, https://doi.org/10.1177/1469540517736560.

Penaloza, L. and L. Price. 1993. 'Consumer Resistance: A Conceptual Overview.' Advances in Consumer Research 20 (1): 123-128.

Roux, D. 2007. 'Consumer Resistance: Proposal for an Integrative Framework.' Recherche et Applications en Marketing 22 (4): 59-79, https://doi.org/10.1177/076737010702200403.

Rychtaříková, J. 2000. 'Demographic Transition or Demographic Shock in Recent Population Development in the Czech Republic.' Acta Universitatis Carolinae Geographica 35: 89-102.

Schor, J. B. 1999. The Overspent American: Why We Want What We Don't Need. New York: Harper Perennial.

Shaw, D. and T. Newholm. 2002. 'Voluntary Simplicity and the Ethics of Consumption.' Psychology \& Marketing 19 (2): 167-185, https://doi.org/10.1002/mar.10008.

Šimon, M. 2014. 'Exploring Counterurbanisation in a Post-Socialist Context: Case of the Czech Republic.' Sociologia ruralis 54 (2): 117-142, https://doi.org/10.1111/j.1467-9523.2012.00576.x.

Smith, A. and A. Stenning. 2006. 'Beyond Household Economies: Articulations and Spaces of Economic Practice in Postsocialism.' Progress in Human Geography 30 (2): 190-213, https://doi.org/10.1191/0309132506ph601oa.

Smith, J. and P. Jehlička. 2007. 'Stories around Food, Politics and Change in Poland and the Czech Republic.' Transactions of the Institute of British Geographers 32 (3): 395-410, https:// doi.org/10.1111/j.1475-5661.2007.00258.x.

Swain, N. 1999. 'Agricultural Restitution and Co-operative Transformation in the Czech Republic, Hungary and Slovakia.' Europe-Asia Studies 51 (7): 1199-1219, https://doi.org/10.1080/09668139998507.

Valor, C., E. M. Díaz and A. Merino. 2017. 'The Discourse of the Consumer Resistance Movement: Adversarial and Prognostic Framings through the Lens of Power.' Journal of Macromarketing 37 (1): 72-84, https://doi.org/10.1177/0276146715627851.

Vaněk, M. and P. Mücke. 2016. Velvet Revolutions: An Oral History of Czech Society. Oxford: Oxford University Press.

Večerník, J. 2009. Czech Society in the 2000s: A Report on Socio-economic Policies and Structures. Prague: Academia.

Zamwel, E., O. Sasson-Levy and G. Ben-Porat. 2014. 'Voluntary Simplifiers as Political Consumers: Individuals Practicing Politics Through Reduced Consumption.' Journal of Consumer Culture 14 (2): 199-217, https://doi.org/10.1177/1469540514526277. 
Zaritska, N. 2015. 'Downshifting as Alternative Lifestyle Practices and Result of Individual Voluntary Life Strategies: Case of Ukrainian society.' Teorija in Praksa 52 (1-2): 220-235.

Zavestoski, S. 2002. 'The Social-Psychological Bases of Anticonsumption Attitudes.' Psychology \& Marketing 19 (2): 149-165, https://doi.org/10.1002/mar.10007. 